Raúl Andrés Mendoza-Sassi

Juraci Almeida Cesar

Patricia Rodrigues da Silva

Giovana Denardin

Mariana Mendes Rodrigues

\section{Risk factors for cesarean section by category of health service}

\section{Fatores de risco para cesárea segundo tipo de serviço}

\begin{abstract}
OBJECTIVE: To analyze the rate of cesarean section and differences in risk factors by category of health service, either public or private.

METHODS: A cross-sectional study was carried out including all pregnant women in labor admitted to hospitals in the city of Rio Grande, Southern Brazil, between January 1 and December 31, 2007. A pre-coded and pretested questionnaire was used to collect on social, demographic, obstetric and newborn care information. Two regression models were constructed: one for public users and the other one for private ones. Poisson regression was used in each model in the multivariate analysis. Prevalence rates and 95\% confidence intervals were calculated for each adjusted factor.
\end{abstract}

RESULTS: The rate of cesarean section was $43 \%$ and $86 \%$ among public and private users. Sociodemographic factors and twin births have a more significant impact among public users as well as number of pregnancies (25\% vs. $13 \%$ reduction in public and private users, respectively) and previous cesarean section ( $86 \%$ vs. $24 \%$ increase in public and private users, respectively). Prenatal care visits and hospital admissions affected the outcome only in women users of public services.

CONCLUSIONS: Cesarean section rates were high in both groups studied, but it was twice as high among women cared in the private sector. Associated factors differ in magnitude by category of service used.

DESCRIPTORS: Cesarean Section. Risk Factors. Socioeconomic Factors. Health Maintenance Organizations. Supplemental Health. Single Health System. Cross-Sectional Studies.
Divisão População e Saúde. Faculdade de Medicina. Universidade Federal do Rio Grande. Rio Grande, RS, Brasil

\section{Correspondence:}

Raúl Andrés Mendoza-Sassi

R. General Osório, s/n

Campus Saúde

96200-400 Rio Grande, RS, Brasil

E-mail: rmend@vetorial.net 


\section{RESUMO}

OBJETIVO: Analisar a taxa de cesárea e fatores associados à sua ocorrência segundo serviço de saúde utilizado, público ou privado.

MÉTODOS: Foi realizado estudo transversal entre $1^{\circ}$ de janeiro e 31 de dezembro de 2007 com todas as gestantes que deram à luz nos hospitais da cidade de Rio Grande, RS. As gestantes foram entrevistadas, utilizando-se um questionário testado e pré-codificado com questões sociodemográficas, obstétricas e relacionadas ao recém-nascido. Foram desenvolvidos dois modelos de predição, um para as gestantes internadas pelo Sistema Único de Saúde (público) e outro para as gestantes internadas em serviços privados. Em cada modelo foi realizada uma análise multivariada utilizando a regressão de Poisson, calculando-se as razões de prevalência e seus respectivos intervalos com $95 \%$ de confiança.

RESULTADOS: A taxa de cesárea para o grupo público foi $43 \%$ enquanto no grupo privado foi $86 \%$. Os fatores sociodemográficos e o parto gemelar foram mais importantes no modelo público, assim como o número gravidezes (redução de $25 \%$ vs. $13 \%$ no grupo privado) e cesárea prévia (incremento de $86 \%$ vs. $24 \%$ no privado). Consultas de pré-natal e internações afetaram o desfecho somente no grupo público.

CONCLUSÕES: As taxas de cesárea foram elevadas nos dois grupos, sendo o dobro no serviço privado. Os fatores de risco são diferentes em magnitude, segundo o tipo de gestante.

\section{DESCRITORES: Cesárea. Fatores de Risco. Fatores Socioeconômicos. Sistemas Pré-Pagos de Saúde. Saúde Suplementar. Sistema Único de Saúde. Estudos Transversais.}

\section{INTRODUCTION}

Cesarean section (C-section) rates have continuously increased over recent decades. This phenomenon has occurred in developed countries ${ }^{14,15}$ as well as in Latin America, ${ }^{23}$ including Brazil. ${ }^{2}$ In Brazil, cesarean rates have grown from $15 \%$ in the 1970 s to $43 \%$ in 2005 , way higher than $15 \%$ recommended by the World Health Organization (WHO).

Some of the reasons associated with this high rate are related to health service characteristics..$^{22,25} \mathrm{~A}$ recent study of the Brazilian National Supplemental Health Agency (ANS, which regulates private insurance) reported that cesarean section rates among privatelyinsured women were as high as $80 \%$ in $2006^{a}$ while it is was $26 \%$ in the public Brazilian National Health System (SUS), ${ }^{\mathrm{b}}$ a rate that is high but closer to that recommended.

Although the same surgical procedure is performed and sometimes they are performed by the same doctors and in the same health facilities - there is a difference between public and private systems that is more related to women's characteristics (for example, sociodemographic and obstetric factors) and medical practice rather than to established technical guidelines. ${ }^{17,19}$

It is essential to understand the differences in associated factors for C-section between categories of health service. Most research has focused on associated factors in public services users or addressed this issue considering together women from both public and private health services. There is little information about risk factors for cesarean section in the private sector and differences between public and private services.

The objective of the present study was to analyze cesarean rates and differences of factors associated between public and private health services.

a Agência Nacional de Saúde Suplementar. Parto Normal. Movimento ANS em favor do parto normal e da redução das cesarianas desnecessárias no setor suplementar. Rio de Janeiro; 2007 [cited 2008 May 07]. Available from: http://www.ans.gov.br/portal/upload/ biblioteca/carta_parto_normal.pdf

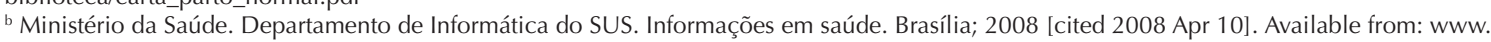
datasus.gov.br. 


\section{METHODS}

A cross-sectional was carried out in all public or private hospitals in the city of Rio Grande, Southern Brazil, between January 1 and December 31, 2007. The sample included all women in labor living in the city who delivered at least one child weighting $\geq 500 \mathrm{~g}$ with a gestational age $\geq 20$ weeks.

The study was part of a larger study designed to analyze perinatal care in the city and included all women $(2,591)$ who delivered during the aforementioned period. At the end of the study, 2,557 subjects were recruited (1.3\% loss). Of 34 losses, one refused to participate and the rest were not found (most of them were private care users) after many attempts. With this sample size, the study had a statistical power of $90 \%$ or higher for identifying significant associations according to the following parameters: 95\% confidence level; relative risk of two or more; non-exposed to exposed ratio from 1:1 to 10:1 and a cesarean section rate in non-exposed of $10 \%$ or higher. In the final sample, 2,023 (79.1\%) women were users of public and $534(20.9 \%)$ of private services.

Mothers were interviewed within 24 hours after delivery. A team consisting of ten previously trained interviewers applied a pre-coded and pre-tested questionnaire. The questionnaire collected sociodemographic information, past and current obstetric history, morbidities during pregnancy, and newborn characteristics. Ten percent of the subjects were re-interviewed after hospital discharge for quality control.

The outcome of interest was type of delivery (cesarean section or vaginal delivery), which was categorized according to health service (public-SUS or private). Information was collected in the interviews and from medical records. Independent variables analyzed were: a) sociodemographic: age, skin color, education, per capita family income and living with a partner; b) past obstetric history: number of pregnancies and number of previous cesarean sections; c) current obstetric history: planned pregnancy, number of prenatal care visits, prenatal care provided by the same doctor, prenatal care facility, number of ultrasonographies, high blood pressure, diabetes, urinary infection, bleeding in the last gestational trimester, work during last gestational trimester, number of hospital admissions; c) delivery and newborn characteristics: number of newborns, newborn's gender, weight, and head circumference.

Data was entered twice and independently using Epi Info 6.04 software. After correction of amplitude or consistency errors, data was analyzed using Stata 9.2 software. Two models were constructed according to category of health service, one for women users of the public sector and the other one for private sector users. The sample characteristics and cesarean rates were calculated and compared. In the bivariate analysis prevalence ratios (PR) and 95\% confidence intervals
(95\% CI) for cesarean section and independent variables in each model were estimated. A multivariate analysis was carried out using Poisson regression with robust confidence intervals and a four-level hierarchical analysis model. ${ }^{24}$ The first level included sociodemographic variables; the second level, past obstetric history; the third level included current obstetric history; and the fourth level, newborn and delivery characteristics. At each level, all variables were included and those with a $p$-value $\leq 0.20$ were retained and adjusted for the next level, using backward stepwise regression. PR and 95\% CI were estimated at each level and statistical significance was assessed using the Wald test. When ordinal variables had three or more categories and a trend was observed, a linear trend test was performed. When no trend was detected, a heterogeneity test was used. A p-value of 0.05 or less for a two-tail test was specified for all statistical analysis. The analyses were carried out in the same manner and with the same variables for both models (public and private).

The study was approved by the Research Ethics Committee of Universidade do Rio Grande.

\section{RESULTS}

The cesarean section rate was $51.6 \%$ in the entire sample; $42.6 \%$ among public (SUS) users and 85.8\% among private users.

Table 1 shows the sample characteristics for the two models. Compared to private users, public users were younger, less educated, had lower per capita family income, and a higher proportion of women with black/ other skin color and not living with a partner was seen. Public users had a larger number of previous pregnancies and cesarean rates. The proportion of women attending prenatal care was similar between both groups (94.7\% vs. $99.8 \%$ ), but mean number of visits was higher among private users (10.2 vs. 6.5). Privately-insured women had twice as many ultrasonographies (5.3 vs. 2.5). Half of public users were provided prenatal care in primary care facilities, while most of private users attended a physician's private office. There was a higher prevalence of morbidities and hospital admissions during pregnancy among users of public services.

No significant differences were found between newborn weight (public: mean 3,198 g, SD 567; private: 3,185, SD 494; $p=0.6$ ) and premature birth rate (public: $17.3 \%$; private: $13.5 \% ; p=0.06)$. Head circumference $(p=0.04)$ was statistically significant though slightly different between children delivered in public (mean $34.36 \mathrm{~cm}$, SD 2.14) and private services (mean 34.57, SD 1.82).

Table 2 presents significant factors according to the bivariate analysis for both models. In the public model, all sociodemographic factors were associated with the outcome, which was not seen in the private model. 
Table 1. Sample characteristics per category of health service. Rio Grande, Southern Brazil, 2008. (N=2,557)

\begin{tabular}{|c|c|c|c|c|c|}
\hline \multirow{2}{*}{ Variable } & \multicolumn{2}{|c|}{ Public service $(n=2023)$} & \multicolumn{2}{|c|}{ Private service $(n=534)$} & \multirow{2}{*}{$\mathrm{p}$} \\
\hline & $\%$ & $\mathrm{n}$ & $\%$ & $\mathrm{n}$ & \\
\hline \multicolumn{6}{|l|}{ Age (years) } \\
\hline 15 to 19 & 23.4 & 474 & 7.9 & 42 & $0.001^{\mathrm{a}}$ \\
\hline 20 to 24 & 30.2 & 412 & 19.8 & 106 & \\
\hline 25 to 29 & 22.4 & 453 & 32.8 & 175 & \\
\hline 30 or + & 23.9 & 484 & 39.5 & 211 & \\
\hline \multicolumn{6}{|l|}{ Skin color } \\
\hline White & 66.4 & 1343 & 81.5 & 435 & $0.001^{\mathrm{a}}$ \\
\hline Black/other & 33.6 & 680 & 18.5 & 99 & \\
\hline \multicolumn{6}{|l|}{ Living with a partner } \\
\hline No & 19.7 & 398 & 7.9 & 42 & $0.001^{\mathrm{a}}$ \\
\hline Yes & 80.3 & 1625 & 92.1 & 492 & \\
\hline \multicolumn{6}{|l|}{ Education } \\
\hline 0 to 4 & 15.3 & 310 & 2.2 & 12 & $0.001^{\mathrm{a}}$ \\
\hline 5 to 8 & 42.8 & 466 & 10.7 & 57 & \\
\hline 9 to 11 & 38.8 & 784 & 53.8 & 287 & \\
\hline 12 or + & 3.1 & 63 & 33.3 & 178 & \\
\hline \multicolumn{6}{|l|}{ Income (minimum wages) } \\
\hline 0 to $1 / 2$ & 49.5 & 1001 & 5.4 & 29 & $0.001^{\mathrm{a}}$ \\
\hline$+1 / 2$ to 1 & 31.5 & 638 & 21.7 & 116 & \\
\hline+ than 1 & 19.0 & 384 & 72.9 & 389 & \\
\hline \multicolumn{6}{|l|}{ Number of pregnancies } \\
\hline 1 & 37.7 & 762 & 46.3 & 247 & $0.001^{\mathrm{a}}$ \\
\hline 2 & 26.5 & 536 & 30.9 & 165 & \\
\hline 3 & 14.9 & 302 & 15.5 & 83 & \\
\hline 4 & 11.0 & 223 & 6.2 & 33 & \\
\hline 5 or + & 9.9 & 200 & 1.1 & 6 & \\
\hline \multicolumn{6}{|l|}{ Previous C-section } \\
\hline No & 69.4 & 1389 & 54.1 & 287 & $0.001^{\mathrm{a}}$ \\
\hline Yes & 30.6 & 612 & 45.9 & 244 & \\
\hline \multicolumn{6}{|l|}{ Pre-natal care } \\
\hline No & 5.3 & 107 & 0.2 & 1 & $0.001^{\mathrm{a}}$ \\
\hline Yes & 94.7 & 1916 & 99.8 & 533 & \\
\hline Pre-natal visits (mean and SD) & 6.6 & 3,54 & 10.2 & 3.40 & $0.001^{b}$ \\
\hline Ultrasonography (mean and SD) & 2.5 & 2.33 & 5.3 & 3.21 & $0.001^{b}$ \\
\hline \multicolumn{6}{|l|}{ Pre-natal care facility } \\
\hline Primary care & 51.0 & 978 & 4.7 & 25 & $0.001^{\mathrm{a}}$ \\
\hline Hospital outpatient clinic & 25.1 & 480 & 1.9 & 10 & \\
\hline Physician's private office & 23.9 & 458 & 93.4 & 498 & \\
\hline \multicolumn{6}{|l|}{ Pre-natal with same doctor } \\
\hline No & 27.8 & 533 & 7.9 & 42 & $0.001^{\mathrm{a}}$ \\
\hline Yes & 72.2 & 1874 & 92.1 & 491 & \\
\hline \multicolumn{6}{|l|}{ High blood pressure } \\
\hline No & 81.1 & 1636 & 85.0 & 454 & $0.04^{\mathrm{a}}$ \\
\hline Yes & 18.9 & 381 & 15.0 & 80 & \\
\hline
\end{tabular}


Table 1 continuation

\begin{tabular}{|c|c|c|c|c|c|}
\hline \multirow{2}{*}{ Variable } & \multicolumn{2}{|c|}{ Public service $(n=2023)$} & \multicolumn{2}{|c|}{ Private service $(n=534)$} & \multirow{2}{*}{$\mathrm{p}$} \\
\hline & $\%$ & $\mathrm{n}$ & $\%$ & $\mathrm{n}$ & \\
\hline \multicolumn{6}{|l|}{ Diabetes } \\
\hline No & 97.0 & 1953 & 97.4 & 520 & $0.7^{\mathbf{a}}$ \\
\hline Yes & 3.0 & 60 & 2.6 & 14 & \\
\hline \multicolumn{6}{|c|}{ Bleeding in $3^{\text {rd }}$ trimester of pregnancy } \\
\hline No & 92.1 & 1862 & 95.3 & 509 & $0.01^{\mathrm{a}}$ \\
\hline Yes & 7.9 & 160 & 4.7 & 25 & \\
\hline \multicolumn{6}{|c|}{ Urinary infection } \\
\hline No & 60.3 & 1211 & 73.9 & 394 & $0.001^{\circ}$ \\
\hline Yes & 39.7 & 798 & 26.1 & 139 & \\
\hline \multicolumn{6}{|c|}{ Hospital admission } \\
\hline No & 84.9 & 1716 & 93.1 & 497 & $0.001^{\mathrm{a}}$ \\
\hline Yes & 15.1 & 306 & 6.9 & 37 & \\
\hline \multicolumn{6}{|c|}{ Working during $3^{\text {rd }}$ trimester } \\
\hline No & 76.1 & 1516 & 57.1 & 305 & $0.001^{\mathrm{a}}$ \\
\hline Yes & 23.9 & 477 & 42.9 & 229 & \\
\hline \multicolumn{6}{|c|}{ Planned pregnancy } \\
\hline No & 61.3 & 1241 & 41.0 & 219 & $0.001^{\mathrm{a}}$ \\
\hline Yes & 38.7 & 782 & 59.0 & 315 & \\
\hline \multicolumn{6}{|c|}{ Twin birth } \\
\hline No & 98.7 & 1997 & 98.5 & 526 & $0.7^{\mathbf{a}}$ \\
\hline Yes & 1.3 & 26 & 1.5 & 8 & \\
\hline
\end{tabular}

${ }^{\text {a }}$ Chi-square test

b Student's t-test

Some similarities were found regarding obstetric factors, but public service had always higher PR. Except for high blood pressure, which was significant in both groups, other morbidities were risk factors only among public users. In regard to newborn factors, only head circumference was associated with the outcome in both models; on the other hand, multiple birth and weight was significant only among public users.

Adjusted PRs for public and private users are described in Table 3 and 4, respectively. Even after adjustment, almost all sociodemographic factors remained significant in the public model, including education and per capita family income (with a linear trend). In the private model, only skin color (with reduction of cesarean section among black women) and income remained significant, but with small effects. In the second level of analysis, the number of previous pregnancies and cesarean sections remained risk factors in both models. However, the magnitude of the effect was greater in the public model ( $25 \%$ vs. $13 \%$ reduction for pregnancy and $86 \%$ vs. $24 \%$ increase for previous cesarean section among public and private users, respectively). For the third level of analysis, risk factors were only significant in the public model, except for high blood pressure, which was significant only among private users. Every prenatal care visit among public users increased the risk of cesarean delivery by $4 \%$ and every hospital admission produced a $12 \%$ increase in risk. In the fourth level of analysis, the association of head circumference and twin birth remained only in the public model.

\section{DISCUSSION}

In the present study cesarean section rate in the city of Rio Grande in 2007 was $52 \%$; $43 \%$ and $86 \%$ among public and private users. Although a few similarities were identified between public and private health services regarding risk factors for cesarean delivery, the number of risk factors and the magnitude of the observed effects were different. In the public group, older age, living with a partner, higher education and income, previous cesarean, more prenatal care visits and hospital admissions, twin birth, and head circumference were all positively associated with the outcome; previous pregnancy had a negative association. For the private group, higher income, previous cesarean and high blood pressure had a direct association with 
Table 2. Crude prevalence ratios for cesarean sections and factors studied in public and private hospital health services. Rio Grande, Southern Brazil, 2008. (N=2,557)

\begin{tabular}{|c|c|c|c|c|}
\hline \multirow{2}{*}{ Variable } & \multirow{2}{*}{$\begin{array}{c}\text { Public service }(\mathrm{n}=2,023) \\
\text { PR }(95 \% \mathrm{Cl})\end{array}$} & \multirow[b]{2}{*}{ p } & Private service $(n=534)$ & \multirow{2}{*}{$\mathrm{p}$} \\
\hline & & & $\operatorname{PR}(95 \% \mathrm{Cl})$ & \\
\hline \multicolumn{5}{|l|}{ Age group } \\
\hline 15 to 19 & 1 & $0.006^{\mathrm{a}}$ & 1 & $0,12^{a}$ \\
\hline 20 to 24 & $1.13(0.97 ; 1.32)$ & & $0.95(0.80 ; 1.12)$ & \\
\hline 25 to 29 & $1.36(1.17 ; 1.59)$ & & $1.03(0.89 ; 1.19)$ & \\
\hline 30 or + & $1.21(1.04 ; 1.42)$ & & $1.07(0.93 ; 1.24)$ & \\
\hline \multicolumn{5}{|l|}{ Skin color } \\
\hline White & 1 & 0.006 & 1 & 0.006 \\
\hline Black/other & $0.86(0.77 ; 0.97)$ & & $0.87(0.75 ; 0.95)$ & \\
\hline \multicolumn{5}{|l|}{ Living with a partner } \\
\hline No & 1 & 0.002 & 1 & 0.25 \\
\hline Yes & $1.26(1.09 ; 1.46)$ & & $1.09(0.94 ; 1.29)$ & \\
\hline \multicolumn{5}{|l|}{ Education } \\
\hline 0 to 4 & 1 & $0.001^{\mathbf{b}}$ & 1 & $0.002^{\mathrm{b}}$ \\
\hline 5 to 8 & $0.97(0,83 ; 1.15)$ & & $1.01(0.70 ; 1.44)$ & \\
\hline 9 to 11 & $1.28(1.09 ; 1.50)$ & & $1.15(0.82 ; 1.60)$ & \\
\hline 12 or + & $1.36(1.04 ; 1.80)$ & & $1.19(0.86 ; 1.66)$ & \\
\hline \multicolumn{5}{|l|}{ Income (min. wage) } \\
\hline 0 to $1 / 2$ & 1 & $0.001^{b}$ & 1 & $0.01^{\mathrm{a}}$ \\
\hline$+1 / 2$ to 1 & $1.17(1.04 ; 1.32)$ & & $0.92(0.75 ; 1.11)$ & \\
\hline+1 & $1.37(1.21 ; 1.55)$ & & $1.07(0.91 ; 1.27)$ & \\
\hline Number of pregnancies & $0.94(0.91 ; 0.98)$ & 0.001 & $0.99(0.96 ; 1.03)$ & 0.7 \\
\hline C-sections & $1.56(1.51 ; 1.61)$ & 0.001 & $1.12(1.09 ; 1.13)$ & 0.001 \\
\hline Pre-natal care visit & $1.06(1.05 ; 1.07)$ & 0.001 & $1.01(1.002 ; 1.02)$ & 0.02 \\
\hline Ultrasonography & $1.06(1.05 ; 1.08)$ & 0.001 & $1,01(0.99 ; 1.02)$ & 0.06 \\
\hline Hospital admissions & $1.17(1.11 ; 1.23)$ & 0.001 & $1.01(0.90 ; 1.12)$ & 0.9 \\
\hline \multicolumn{5}{|l|}{ Pre-natal care facility } \\
\hline Primary care & 1 & $0.001^{\mathbf{b}}$ & 1 & $0.8^{\mathrm{a}}$ \\
\hline Hospital outpatient clinic & $1.30(1.15 ; 1.46)$ & & $0.95(0.67 ; 1.36)$ & \\
\hline Physician's private office & $1.38(1.22 ; 1.55)$ & & $1.02(0.86 ; 1.22)$ & \\
\hline \multicolumn{5}{|l|}{ Pre-natal with same doctor } \\
\hline No & 1 & 0.02 & 1 & 0.4 \\
\hline Yes & $0.88(0.79 ; 0.98)$ & & $1.06(0.92 ; 1.24)$ & \\
\hline \multicolumn{5}{|l|}{ High blood pressure } \\
\hline No & 1 & 0.001 & 1 & 0.001 \\
\hline Yes & $1.30(1.17 ; 1.46)$ & & $1.15(1.08 ; 1.22)$ & \\
\hline \multicolumn{5}{|l|}{ Diabetes } \\
\hline No & 1 & 0.03 & 1 & 0.3 \\
\hline Yes & $1.31(1.03 ; 1.65)$ & & $1.09(0.93 ; 1.26)$ & \\
\hline \multicolumn{5}{|l|}{ Bleeding in $3^{\text {rd }}$ trimester } \\
\hline No & 1 & 0.009 & 1 & 0.7 \\
\hline Yes & $0.73(0.58 ; 0.93)$ & & $1,03(0.88 ; 1.19)$ & \\
\hline \multicolumn{5}{|l|}{ Working during $3^{\text {rd }}$ trimester } \\
\hline No & 1 & 0.002 & 1 & 0.5 \\
\hline Yes & $1.19(1.06 ; 1.33)$ & & $1,02(0.96 ; 1.10)$ & \\
\hline
\end{tabular}


Table 2 continuation

\begin{tabular}{|c|c|c|c|c|}
\hline Variable & $\begin{array}{c}\text { Public service }(n=2,023) \\
\text { PR }(95 \% C l)\end{array}$ & $\mathrm{p}$ & $\begin{array}{c}\text { Private service }(n=534) \\
\text { PR }(95 \% \mathrm{Cl})\end{array}$ & $\mathrm{p}$ \\
\hline \multicolumn{5}{|l|}{ Planned pregnancy } \\
\hline No & 1 & 0.001 & 1 & 0.8 \\
\hline Yes & $1.18(1.07 ; 1.31)$ & & $1.01(0.94 ; 1.08)$ & \\
\hline \multicolumn{5}{|l|}{ Twin birth } \\
\hline No & 1 & 0,001 & 1 & 0.5 \\
\hline Yes & $2.01(1.70 ; 2.40)$ & & $0.87(0.58 ; 1.30)$ & \\
\hline Newborn weight (100 grams) & $1.02(1.01 ; 1.03)$ & 0.001 & $1.005(0.99 ; 1.01)$ & 0.2 \\
\hline Head circumference (each 1cm) & $1.07(1.04 ; 1.09)$ & 0.001 & $1.03(1.01 ; 1.05)$ & 0.01 \\
\hline
\end{tabular}

cesarean delivery, while black skin color and previous pregnancy were inversely associated.

With respect to methodological limitations, it should be discussed the study design. It is known that crosssectional studies are weak for establishing causal relationship. But in this case, where the outcome (a surgical procedure) is preceeded by the risk factors studied, the direction of causality does not seem to be a problem. Another potential methodological issue is the number of losses, but as they were slightly higher than $1 \%$, it is very unlikely it could have affected the results. Some of the non-significant associations could be attributed to a lack of statistical power. Although the sample size initially studied had a good power, when constructing the two models, it may have been reduced due to losses. This would particularly affect the private model, which had a smaller number of observations. However, those associations that were not significant, or those that lost significance after adjustment, showed in most situations very small effects and narrow CI, which somehow minimized the problem.

The cesarean section rate in the entire sample was high and way off that recommended by WHO. It is even higher than that reported nationwide $(43 \% \text { in } 2005)^{\mathrm{a}}$ and in the neighbor city of Pelotas (45\% in 2004). ${ }^{5}$ However, it shows a rising trend which must be taken into consideration.

Comparison of both models showed relevant issues regarding the factors studied as well as the risk magnitude. Both groups of users had high cesarean section rates, but the rates was twice as high as among private than public users and closer to that reported by ANS in $2006(80 \%)$. Further studies are needed to explore the reasons why four out of five women in private services and four out of ten in the public ones underwent surgical delivery instead of normal vaginal delivery, but it is certainly has other explanation than that of technical indications.

Another major issue is sociodemographic differences. Other studies have identified them as risk factors, ${ }^{6-8,10}$ and in the present study this was seen in the public model, except for skin color. As in other child or mother outcomes, ${ }^{13}$ better-off women are more likely to have a cesarean section. Those living with a partner also had higher risk of cesarean delivery. This finding may be explained by a will to preserve their sexual function. ${ }^{9,27}$ Among private users, the socioeconomic factors that remained in the model were income and skin color. With respect to income, although there was a difference, it was small as expected since women in this group are more affluent. The negative association between cesarean delivery and skin color has been described in other studies, ${ }^{10,21}$ and for other child and mother outcomes, ${ }^{3,13,20}$ and is explained by poor quality of prenatal care and socioeconomic disadvantages. However, it should be noted that it remains a factor in the model that exclusively analyzed the private sector, even after adjustment for income. In addition, when those who attended six or more prenatal care visits in the private sector were analyzed, no significant difference was found between non-white and white women (94.8 vs. $97 \%, p=0.3$ ). Therefore, we can assume that other factors may have affected the lower number of cesareans among non-white women users of private services.

Additional issues associated to cesarean sections are obstetric and newborn factors, which were also identified in other studies ${ }^{6,10,11,22}$ as major determinant of cesarean section rate in both groups. However, there were differences according to the category of health service. It was clear for prenatal care. Every visit in the public sector increased the risk of cesarean by $4 \%$, even after adjusting for prenatal care with the same physician (which was not significant), while in the private group

a Ministério da Saúde. Departamento de Informática do SUS. Informações em saúde. Brasília; 2008 [cited 2008 Apr 10]. Available from: www.datasus.gov.br 
Table 3. Adjusted prevalence ratios and 95\% Cl for cesarean sections in the public health sector. Rio Grande, Southern Brazil, 2008.

\begin{tabular}{|c|c|c|}
\hline Variable & PR $(95 \% \mathrm{Cl})$ & $\mathrm{P}$ \\
\hline \multicolumn{3}{|l|}{ Age $^{\mathbf{a}}$ (years) } \\
\hline 15 to 19 & 1 & $0.04^{\mathrm{e}}$ \\
\hline 20 to 24 & $1.04(0.89 ; 1.22)$ & \\
\hline 25 to 29 & $1.23(1.05 ; 1.44)$ & \\
\hline 30 or + & $1.12(0.95 ; 1.31)$ & \\
\hline \multicolumn{3}{|l|}{ Living with a partner ${ }^{\mathbf{a}}$} \\
\hline No & 1 & $0.03^{\mathbf{e}}$ \\
\hline Yes & $1.18(1.03 ; 1.37)$ & \\
\hline \multicolumn{3}{|l|}{ Schooling $^{\mathbf{a}}$} \\
\hline 0 to 4 & 1 & $0.006^{\mathbf{e}}$ \\
\hline 5 to 8 & $0.99(0.84 ; 1.18)$ & \\
\hline 9 to 11 & $1.21(1.02 ; 1.44)$ & \\
\hline 12 or + & $1.18(0.89 ; 1.57)$ & \\
\hline \multicolumn{3}{|l|}{ Skin color ${ }^{\mathrm{a}}$} \\
\hline White & 1 & 0.08 \\
\hline Black/other & $0.90(0.80 ; 1.01)$ & \\
\hline \multicolumn{3}{|l|}{ Income (min. wage $)^{\mathbf{a}}$} \\
\hline 0 to $1 / 2$ & 1 & $0.01^{\mathrm{f}}$ \\
\hline$+1 / 2$ to 1 & $1.08(0.95 ; 1.22)$ & \\
\hline+1 & $1.19(1.04 ; 1.37)$ & \\
\hline Number of pregnancies ${ }^{\mathbf{b}}$ & $0.75(0.70 ; 0.81)$ & 0.001 \\
\hline Previous C-sections ${ }^{\mathbf{b}}$ & $1.86(1.77 ; 1.95)$ & 0.001 \\
\hline Pre-natal care visits ${ }^{\mathbf{c}}$ & $1.04(1.02 ; 1.05)$ & 0.001 \\
\hline Hospital admissions ${ }^{\mathbf{c}}$ & $1.12(1.05 ; 1.19)$ & 0.001 \\
\hline \multicolumn{3}{|l|}{ Pre-natal care facility ${ }^{\mathbf{c}}$} \\
\hline Primary care & 1 & $0.02^{\mathbf{e}}$ \\
\hline Hospital outpatient clinic & $1.16(1.04 ; 1.30)$ & \\
\hline Physician's private office & $1.11(0.99 ; 1.25)$ & \\
\hline \multicolumn{3}{|l|}{ Twin birth ${ }^{\mathbf{d g}}$} \\
\hline No & 1 & 0.001 \\
\hline Yes & $1.73(1.33 ; 2.26)$ & \\
\hline Head circumference $(\text { each } 1 \mathrm{~cm})^{\mathbf{d g}}$ & $1.04(1.02 ; 1.07)$ & 0.002 \\
\hline
\end{tabular}

${ }^{\text {a }}$ First level model

b Second level model

${ }^{\mathrm{c}}$ Third level model

${ }^{\text {d }}$ Forth level model

e Heterogeneity test

${ }^{f}$ Linear trend test

g Adjusted for premature birth

it had no effect at all. If one considers all efforts that are made to ensure pregnant women adequate number of prenatal care visits, it is a paradoxical that more care can lead to a higher risk of cesarean section, thereby increasing the likelihood of negative outcomes for the child and the mother. ${ }^{26}$ One of the explanations for this association would be that women with high-risk pregnancies have more prenatal care visits, and therefore have higher cesarean section rate. Although this is true, it cannot explain by itself the high rate of cesarean 
Table 4. Adjusted prevalence ratios and $95 \% \mathrm{Cl}$ for cesarean sections in the private health sector. Rio Grande, Southern Brazil, 2008.

\begin{tabular}{|c|c|c|}
\hline Variable & PR $(95 \% \mathrm{Cl})$ & $\mathrm{p}$ \\
\hline \multicolumn{3}{|l|}{ Skin color ${ }^{\mathrm{a}}$} \\
\hline White & 1 & 0.01 \\
\hline Black/other & $0.86(0.77 ; 0.97)$ & \\
\hline \multicolumn{3}{|l|}{ Income (minimum wage) ${ }^{\mathbf{a}}$} \\
\hline 0 to $1 / 2$ & 1 & $0.03^{\mathrm{e}}$ \\
\hline$+1 / 2$ to 1 & $0.91(0.76 ; 1.11)$ & \\
\hline+1 & $1.06(0.90 ; 1.24)$ & \\
\hline Number of pregnancies ${ }^{\mathbf{b}}$ & $0.87(0.79 ; 0.95)$ & 0.001 \\
\hline Previous C-sections ${ }^{\mathbf{b}}$ & $1.24(1.16 ; 1.33)$ & 0.001 \\
\hline \multicolumn{3}{|l|}{ High blood pressure ${ }^{c}$} \\
\hline No & 1 & \\
\hline Yes & $1.14(1.07 ; 1.21)$ & 0.001 \\
\hline Cephalic perimeter $(1 \mathrm{~cm})^{\mathbf{d g}}$ & $1.02(0.99 ; 1.04)$ & 0.1 \\
\hline \multicolumn{3}{|l|}{${ }^{a}$ First level model } \\
\hline \multicolumn{3}{|l|}{ b Second level model } \\
\hline \multicolumn{3}{|l|}{${ }^{\mathbf{c}}$ Third level model } \\
\hline \multicolumn{3}{|l|}{ d Forth level model } \\
\hline \multicolumn{3}{|l|}{${ }^{\mathbf{e}}$ Heterogeneity test } \\
\hline \multicolumn{3}{|l|}{ f Linear trend test } \\
\hline${ }^{g}$ Adjusted for premature birth & & \\
\hline
\end{tabular}

delivery seen in public services ( $40 \%$ ), considering that the study was population-based and representative of all pregnant women who sought public care.

Other obstetric and newborn variables showed different values according to the category of service. Although it is a factor identified in other studies, ${ }^{25}$ the effect of number of previous cesarean sections was very high in the public sector ( $86 \%$ compared to $24 \%$ in the private sector). Twin birth was only important in public services. As for head circumference, even after adjustment for premature births, pregnant women users of public services had an increased risk, while no difference was found after adjustment among private users.

All these differences are extremely disproportionate among women per category of health service they use, but they are not different in their final health need (delivering a child). It is barely logical that they only occur due to technical or scientific reasons. Technical indications of cesarean sections cannot be that high and that different between different categories of services. But a different medical practice according to health sector could explain the higher and different rates seen and the differences in factors associated to cesarean section.

Our study provided input that should be used to further explain these differences. Other studies on the same subject pointed to two other factors that could explain our results: mother's behavior and preferences, and doctor's practice. As for mother's behavior and preferences, studies have found that pregnant women's choice, ${ }^{15}$ even of those with low or middle condition, ${ }^{4}$ has an influence on the outcome. Furthermore, apparently it occurs after hospital admission, ${ }^{17}$ suggesting that for some reason the mother changes her mind about vaginal delivery. As for doctor's practice, there is evidence that medical practice is very important for the outcome in both public and private services. ${ }^{12,18}$ There seems to be a disagreement between what doctors believe would be their patients' preferred route of delivery and what women actually want. ${ }^{9}$

In conclusion, the present study adds new knowledge about risk factors for cesarean section, and shows that they are not consistent when analyzed individually according to category of health service. The explanation is probably due to differences in women's and doctors' behaviors in both public and private services rather than adverse clinical conditions.

The Brazilian cesarean section rate is a public health concern and must be reduced. Some interventions to reduce these rates have focused on the main agents involved and others have been specific to health services. Promoting conscientious practices among physicians, and providing pregnant women with information about the benefits of vaginal delivery are some of them. Other interventions under consideration would be payment limitation for cesarean sections in the private health sector, as seen in public services. We suggest that health institutions, in addition to the second-opinion strategy, ${ }^{16}$ which is quite effective at reducing unnecessary cesarean sections, ${ }^{1}$ establish a specific hospital committee to review cesarean section indications following the same procedures as for other hospital events (e.g., hospital infection, deaths, and medical records quality).

A multi-focal strategy that includes cultural, financial, management and medical practice interventions could have impact on reducing the cesarean section rate in Brazil.

\section{REFERENCES}

1. Althabe F, Belizán JM, Villar J, Alexander S, Bergel E, Ramos S, et al. Mandatory second opinion to reduce rates of unnecessary caesarean sections in Latin
America: a cluster randomised controlled trial. Lancet. 2004;363(9425):1934-40. DOI:10.1016/S01406736(04)16406-4 
2. Barros FC, Vaughan JP, Victora CG, Huttly SR. Epidemic of caesarean sections in Brazil. Lancet. 1991;338(8760):167-9. DOI:10.1016/01406736(91)90149-J

3. Barros FC, Victora CG, Horta BL. Ethnicity and infant health in Southern Brazil. A birth cohort study. Int J Epidemiol. 2001;30(5):1001-8. DOl:10.1093/ ije/30.5.1001

4. Behágue DP, Victora CG, Barros FC. Consumer demand for caesarean sections in Brazil: informed decision making, patient choice, or social inequality? A population based birth cohort study linking ethnographic and epidemiological methods. BMJ. 2002;324(7343):942-5. DOI:10.1136/ bmj.324.7343.942

5. Cesar JA, Matijasevich A, Santos IS, Barros AJ, Diasda-Costa JS, Barros FC, et al. The use of maternal and child health services in three population-based cohorts in Southern Brazil, 1982-2004. Cad Saude Publica. 2008;24(Suppl 3):S427-36. DOI:10.1590/S0102311X2008001500008

6. D'Orsi E, Chor D, Giffin K, Angulo-Tuesta A, Barbosa GP, Gama AS, et al. Factors associated with cesarean sections in a public hospital in Rio de Janeiro, Brazil. Cad Saude Publica. 2006;22(10):2067-78. DOI:10.1590/S0102-311X2006001000012

7. Fabri RH, Murta EF. Socioeconomic factors and cesarean section rates. Int I Gynaecol Obstet. 2002;76(1):87-8. DOI:10.1016/S00207292(01)00544-6

8. Faisal-Cury A, Menezes PR. Fatores associados à preferência por cesareana. Rev Saude Publica. 2006;40(2):226-32. DOI:10.1590/S003489102006000200007

9. Faúndes A, Pádua KS, Osis MJ, Cecatti JG, Sousa $\mathrm{MH}$. Opinião de mulheres e médicos brasileiros sobre a preferência pela via de parto. Rev Saude Publica. 2004;38(4):488-94. DOI:10.1590/S003489102004000400002

10. Freitas PF, Drachler ML, Leite JC, Grassi PR. Desigualdade social nas taxas de cesariana em primíparas no Rio Grande do Sul. Rev Saude Publica. 2005;39(5):761-7. DOI:10.1590/S003489102005000500010

11. Gomes UA, Silva AA, Bettiol H, Barbieri MA. Risk factors for the increasing caesarean section rate in Southeast Brazil: a comparison of two birth cohorts, 1978-1979 and 1994. Int J Epidemiol. 1999;28(4):68794. DOI:10.1093/ije/28.4.687

12. Hopkins K. Are Brazilian women really choosing to deliver by cesarean? Soc Sci Med. 2000;51(5):725-40. DOI:10.1016/S0277-9536(99)00480-3

13. Leal MC, Gama SG, Cunha CB. Desigualdades raciais, sociodemográficas e na assistência ao pré-natal e ao parto, 1999-2001. Rev Saude Publica. 2005;39(1):100-7. DOI:10.1590/S003489102005000100013

14. Mayor S. Caesarean section rate in England reaches 22\%. BMJ. 2002;324(7346):1118. DOl:10.1136/ bmj.324.7346.1118/d
15. NIH State-of-the-Science Conference Statement on cesarean delivery on maternal request. NIH Consens State Sci Statements. 2006;23(1):1-29.

16. Osis MJ, Cecatti JG, Padua KS, Faundes A. Brazilian doctors' perspective on the second opinion strategy before a C-section. Rev Saude Publica. 2006;40(2):233-9. DOI:10.1590/S003489102006000200008

17. Potter JE, Berquó E, Perpétuo IH, Leal OF, Hopkins K, Souza MR, et al. Unwanted caesarean sections among public and private patients in Brazil: prospective study. BMJ. 2001;323(7322):1155-8. DOI:10.1136/ bmj.323.7322.1155

18. Potter JE, Hopkins K, Faúndes A, Perpétuo I. Women's autonomy and scheduled cesarean sections in Brazil: a cautionary tale. Birth. 2008;35(1):33-40. DOI:10.1111/ j.1523-536X.2007.00209.x

19. Roberts CL, Tracy S, Peat B. Rates for obstetric intervention among private and public patients in Australia: population based descriptive study. BMJ. 2000;321(7254):137-41. DOI:10.1136/ bmj.321.7254.137

20. Silva AA, Lamy-Filho F, Alves MT, Coimbra LC, Bettiol $\mathrm{H}$, Barbieri MA. Risk factors for low birthweight in north-east Brazil: the role of caesarean section. Paediatr Perinat Epidemiol. 2001;15(3):257-64. DOI:10.1046/j.1365-3016.2001.00358.x

21. Silva LM, Silva RA, Silva AA, Bettiol H, Barbieri MA. Racial inequalities and perinatal health in the southeast region of Brazil. Braz J Med Biol Res. 2007;40(9):118794. DOI:10.1590/S0100-879X2006005000144

22. Silveira DS, Santos IS. Fatores associados à cesariana entre mulheres de baixa renda em Pelotas, Rio Grande do Sul, Brasil. Cad Saude Publica. 2004;20(Supl 2):S231-41.

23. Trujillo-Hernández B, Rios-Silva M, Huerta $M$, Trujillo X, Vásquez C, Millán-Guerrero R. Frequency of, indications for and clinical epidemiological characteristics of first time cesarean section, compared with repeated cesarean section. Arch Gynecol Obstet. 2002;267(1):27-32. DOI:10.1007/s00404-001-0255-6

24. Victora $\mathrm{CH}$, Huttly SR, Fuchs SC, Olinto MT. The role of conceptual frameworks in epidemiological analysis: a hierarchical approach. Int J Epidemiol. 1997;26(1):224-7. DOI:10.1093/ije/26.1.224

25. Villar J, Valladares E, Wojdyla D, Zavaleta N, Carroli G, Velazco A, et al. Caesarean delivery rates and pregnancy outcomes: the 2005 WHO global survey on maternal and perinatal health in Latin America. Lancet. 2006;367(9525):1819-29. DOI:10.1016/S01406736(06)68704-7.

26. Villar J, Carroli G, Zavaleta N, Donner A, Wojdyla D, Faundes A, et al. Maternal and neonatal individual risks and benefits associated with caesarean delivery: multicentre prospective study. BMI. 2007;335(7628):1025. DOI:10.1136/ bmj.39363.706956.55

27. Wax JR, Cartin A, Pinette MG, Blackstone J. Patient choice cesarean: an evidence-based review. Obstet Gynecol Surv. 2004;59(8):601-16. DOI:10.1097/01. OGX.0000133942.76239.57 